Journal of Chemistry and Technologies, 2018, 26(1), 1-8

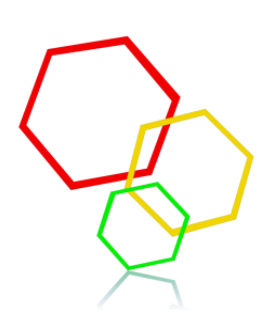

Journal of Chemistry and Technologies

pISSN 2306-871X (Print), ISSN 2313-4984 (Online)

journal homepage: http://chemistry.dnu.dp.ua

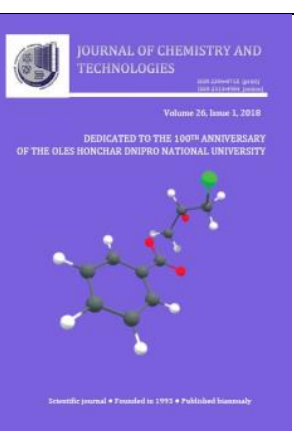

UDC 541.04

\title{
MODIFICATION TECHNOLOGY OF MONTMORILLONITE BY POLYIONENES
}

\author{
Kostyantyn M. Sukhyy*, Elena A. Belyanovskaya, Mikhaylo P. Sukhyy, \\ Vitaliy I. Tomilo \\ State Higher Education Institution 'Ukrainian State University of Chemical Engineering', Gagarine av. 8, Dnipro, \\ 49005, Ukraine
}

Received 18 November 2017; revised 29 November 2017; accepted 04 December 2017

\begin{abstract}
Technology of obtaining montmorillonite modified by polyionenes is developed. Macromolecular polymer intercalation of a quaternary ammonium salt of montmorillonite intercrystalline space is shown to be accompanied with increased interlayer distances from $1.08 \mathrm{~nm}$ to $1.67 \mathrm{~nm}$. The technique of synthesis of montmorillonite modified by polyionenes is suggested. Optimal conditions for sorption of polyionenes molecules with montmorillonite are found to be: the concentration of aqueous dispersion of montmorillonite is $1 \%$, the temperature of the reaction medium is $40{ }^{\circ} \mathrm{C}$, the montmorillonite-polyionene ratio is $3: 1$, the processing time is 24 hours. The mechanism of montmorillonite modification is suggested to involve the next steps: connection of organic cations to montmorillonite surface determined by attachment of organic cations to exchange position during ionexchange adsorption and adsorption of organic cations with acid sylanol groups, i.e. torn bonds on crystal faces. These processes are shown to result in more perfect structure by organic cations adsorption with acid sylanol groups (torn bonds on crystal faces).
\end{abstract}

Keywords: modification, montmorillonite, polyionenes, exfoliation.

\section{ТЕХНОЛОГІЯ МОДИФІКАЦІЇ МОНТМОРІЛЛОНІТА ПОЛІІНЕНАМИ}

\author{
Костянтин М. Сухий*, Олена А. Бєляновська, Михайло П. Сухий, Віталій І. Томіло \\ ДВНЗ «Український держаний хіміко-технологічний університет», пр. Гагаріна 8, Дніпро, 49005, Украина
}

\section{Анотація}

Розроблено технологію отримання монтмориллоніту, модифікованого полііоненами. Показано, що інтеркаляція високомолекулярних полімерів четвертинної амонієвої солі монтморіллонітного міжкристалічного простору супроводжується збільшенням міжшарової відстані від 1.08 нм до 1.67 нм. Запропоновано методику синтезу монтмориллоніту, модифікованого полііоненами. Виявлено оптимальні умови для сорбції молекул полііоненів 3 монтмориллонітом: концентрація водної дисперсії монтмориллоніту становить $1 \%$, температура реакційного середовища $40{ }^{\circ} \mathrm{C}$, співвідношення монтмориллоніту-полііонену $3: 1$, час обробки 24 годин Запропонований механізм модифікації монтморіллоніту включає наступні стадії: з'єднання органічних катіонів з поверхнею монтмориллоніту, що визначається приєднанням органічних катіонів до обмінної позиції при адсорбції та адсорбцію органічних катіонів з кислотними синанольними групами, тобто розірваними зв'язками на поверхнях кристалів. Показано, що ці процеси призводять до більш досконалої структури за рахунок адсорбції органічних катіонів кислотними синанольними групами (розірваними зв'язками на поверхнях кристалів).

Ключові слова: модифікація, монтморилоніт, полііонени, екфоліація.

Corresponding author: tel: (050)4801116; e-mail:ksukhyy@gmail.com (C) 2018 Oles Honchar Dnipro National University doi: $10.15421 / 081801$ 


\title{
ТЕХНОЛОГИЯ МОДИФИКАЦИИ МОНТМОРИЛЛОНИТА ПОЛИИОНЕНАМИ
}

\author{
Константин М. Сухой*, Елена А. Беляновская, Михаил П. Сухой, Виталий И. Томило \\ ГВУЗ «Украинский государственный химико-технологический университет», пр. Гагаріна 8, Дніпро, 49005, \\ Україна
}

\begin{abstract}
Аннотация
Разработана технология получения монтмориллонита, модифицированного полионенами. Показано, что интеркаляция макромолекулярного полимера четвертичной аммониевой соли межмолекулярного пространства монтмориллонита сопровождается увеличением межслоевых расстояний от 1.08 нм до 1.67 нм. Предложена методика синтеза монтмориллонита, модифицированного полионинами. Найдены оптимальные условия для сорбции молекул полионенов с монтмориллонитом: концентрация водной дисперсии монтмориллонита составляет $1 \%$, температура реакционной среды - $40{ }^{\circ} \mathrm{C}$, отношение монтмориллонит-полиионен составляет $3: 1$, время обработки 24 ч. Предполагается, что механизм модификации монтмориллонита включает следующие стадии: подключение органических катионов к поверхности монтмориллонита, определяемое присоединением органических катионов к обменному положению при ионообменной адсорбции и адсорбции органических катионов кислотными силановыми группами, тобто розорванными связями на поверхностях кристаллов. Показано, что эти процессы приводят к более совершенной структуре путем адсорбции органических катионов кислотными группами силанола (разрывы связей на поверхностях кристаллов).
\end{abstract}

Ключевые слова: модификация, монтмориллонит, полионены, эксфолиация.

\section{Introduction}

Global trends of miniaturization indicate objects of science and technology to be decreased up to nano-size because of depletion of miniaturization possibilities with traditional technologies [1-3].

Nano-phase materials science is differed from traditional materials science by developing of innovative materials, their functional parameters being determined not only by microdomain properties but processes occur to be on atomic and molecular level in monolayers and nanovolumes.

Such design can be realized only with molecular clusters and nano-sized particles. Furthermore, micro- nanotechnology transition is not only quantitive but qualitative, physical parametes (fusion temperature, bond energy, interatomic distances, ionic and electronic conductivity, optical and magnetic properties) are revealed non-monotonic dependence on size [4; 5]. Thermodynamical method allows revealing control factors based on homogenic and heterogenic nucleation and studies of particles growth dynamic and structural organisation.

Intercalation of ionogenic organic compounds into porous and layered nanostructures followed by post-intercalation processes is of the utmost interest [6; 7].

Notwithstanding clay mineral modification method certain criteria and general principles of directed regulation of colloid-chemical properties of disperse bodies and their systems ought to be applied [8]. These principles concern with comprehensive investigation of [9-12]:
- structure of disperse phase, i.e. determination of their fine structure, nature, value and energy state of surface;

- structure formation mechanism and influence of various factors on their structuraladsorptive characteristics;

- interaction colloidal phase and disperse medium;

- structure formation in disperse system due to interaction both particles and medium.

These principles are the base for methods of obtaining a lot of clay minerals.

Water-soluble surfactant species with various functional groups are of great significance for control of disperse system properties, such substances being polyionenes included quaternary nitrogen atom in backbone chain. Polyionenes-clay minerals interaction resulted in far-reaching changes of their chemical, surface and porous structure. Increasing of mineral adsorption capacity for hydro carbons is resulted from these processes, it being accompanied with expansive growth of swelling and thyxotropic gelation of organic derivatives in disperse media with various polarity.

Replacement of clay mineral exchange cations with organic cations is stated to be accompanied by expanding of crystal gratings along z-axis and internal surface activation [11; 12]. Highly developed microporous structure occurs to be accessible for adsorption of hydrocarbon molecules and inert gases. According to imbedded ion size, pores diameter and sorbent selectivity to determined substances can be controlled. 
Journal of Chemistry and Technologies, 2018, 26(1), 1-8

With that surface hydrophobisation results in affinity of molecular surface properties for organic media with various polarities. It is supported with increasing of adsorption of some hydro carbons [15], humification and dispergation and heat emission resulted from innerphase solvate interaction with solvent molecules [16].

Interaction of modified minerals and liquid disperse media appears to reveal their important properties, i.e. swelling and thyxotropic coagulation structurization which are determined by used polyionenes, modification extent, concentration and anisotropy of disperse phase properties, presence of polar additives and solvative ability of disperse medium $[15 ; 17 ; 18]$.

Accordingly, the first main task for modeling of processes dealt with conversion of materials filled with fine particles is focused on determination of particles-aggregates interaction energy. Therefore, the second main task for obtaining of polymeric composites with using of nanomaterials is concerned with arrangement of energetic conditions for nanoparticles division
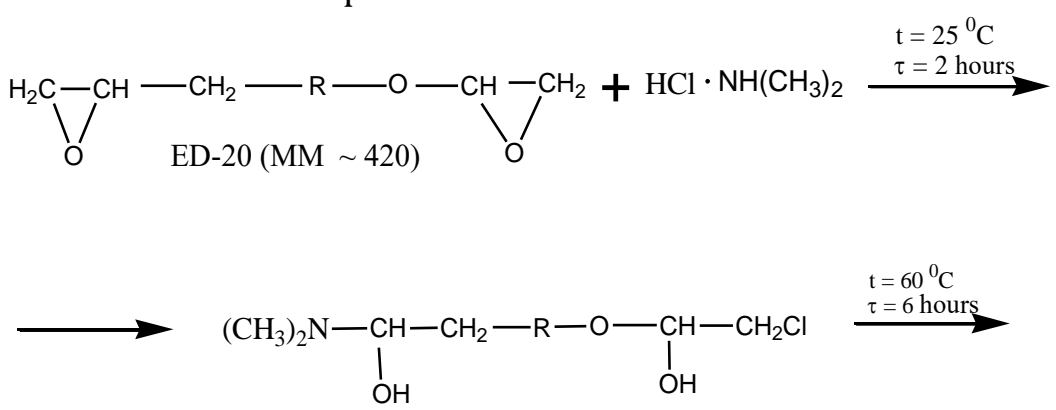

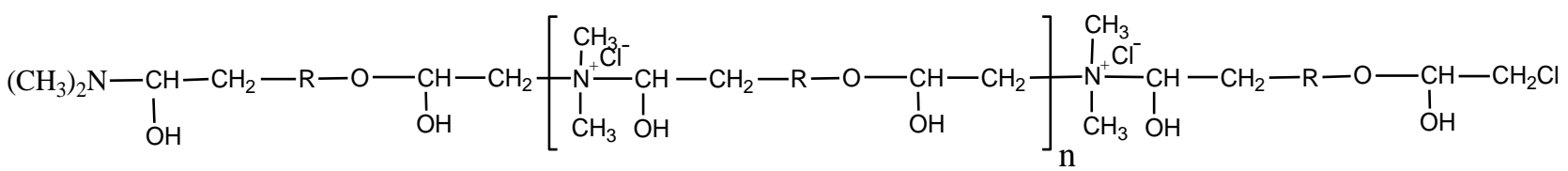<smiles>[R]CC(C)Oc1ccc(C(C)(C)c2ccc(OCC(C)Oc3ccc(C(C)(C)c4ccc(C)cc4)cc3)cc2)cc1</smiles>

Synthesized polyionene represents as solid white-yellow precipitate. To remove the solvent stub polyionene is incubated in dessicator at $60{ }^{\circ} \mathrm{C}$ during 6 hours. Molecular mass of polyionene determined with end groups' titration is stated to be 4500 . followed by their equal distribution. These conditions can be obtained due to choice of optimal ratios operating parameters-design working elements of equipment.

\section{Experimental}

Montmorillonite obtained from bentonite BR ('Dashukov bentonites Ltd', Cherkassy minefield, Ukraine) is studied in present work. Bentonite is grey powder consisted about of $85 \%$ of montmorillonite.

Polyionene based on epoxide diene rubber ED20 is synthesized by known techniques. Solutions in isopropyl alcohol of both $10 \%$ ED-20 and dimethylaminehydrochloride are mixed up in equimolar ratio. The reaction mixture was incubated at $25^{\circ} \mathrm{C}$ during two hours when stirred continuously. Then, polyionene is synthesized with chloramine obtained by addition polymerization. The reaction mixture is incubated at $60^{\circ} \mathrm{C}$ during six hours.

Polyionene obtaining reaction is given below [19]: 
Journal of Chemistry and Technologies, 2018, 26(1), 1-8

montmorillonite because of cationic activity of $\mathrm{Na}^{+}$-montmorillonite exceeds by degree of order cationic activity of $\mathrm{Ca}^{2+}$-montmorilinite and $\mathrm{Mg}^{2+}$-montmorilinite that resulted in exceeding efficiency exchange reaction of $\mathrm{Na}^{+}$and $\mathrm{N}^{+}\left(\mathrm{R}_{3}\right)$. Montmorillonite modification with polyionene concerns with substitution of exchangeable cation on polyionene cation.

Modified montmorillonite is synthesized according to the next techniques:

- elutriation of montmorillonite fraction;

- preparing of $1 \%$ bentonite water dispersion;

- desilting of dispersion during 1 hour followed by separation of montmorillonite dispersion;

- separation and drying of precipitate;

- preparing of $1 \%$ montmorillonite suspension, desilting during 1 hour and decantation of high disperse fraction;

- immixture with water at ratio $1: 100$, disilting during 1 hour and decantation of high disperse fraction.

- elutriation repeated 3-4 time;

Elutriation is carried out to separate high disperse montmorillonite fraction of bentonite.

- activation is carried out by addition $5 \%$ water solution of $\mathrm{Na}_{2} \mathrm{CO}_{3}$ to $1 \%$ montmorillonite water dispersion followed by incubating at 85$85^{\circ} \mathrm{C}$ during $15 \mathrm{~min}$. Then montmorillonite with modified lamenes surface is obtained.

- Modification is carried out according to techniques. Water solution of $15 \%$ polyionenes

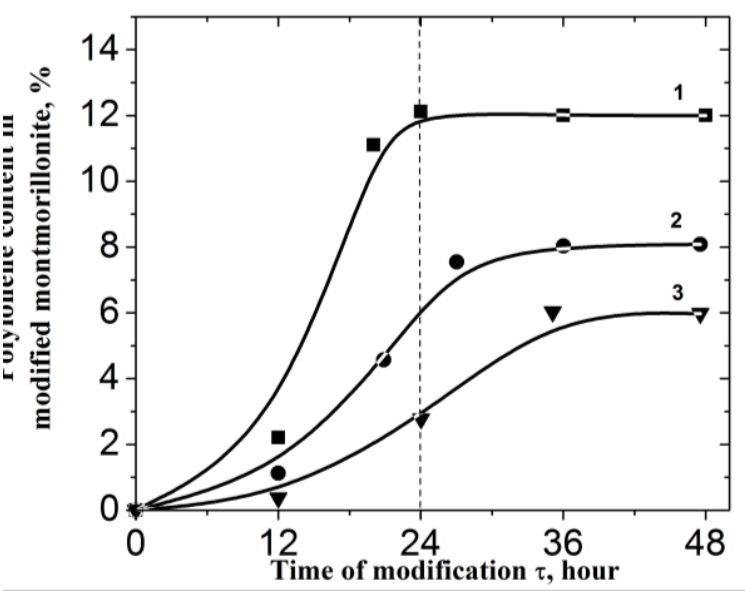

Fig. 1. Kinetic curves of montmorillonite modification process. Montmorillonite-polyionene ratio is $3: 1$. Temeperatures, ${ }^{\circ} \mathrm{C}: 1-40 ; 2-30 ; 3-20$ is added into water dispersion of $1 \%$ of activated montmorillonite when stirred intensively. Mixture is incubated at $40{ }^{\circ} \mathrm{C}$ when stirred during 24 hours. The solid phase is separated with centrifuge and vacuum-dried at $60{ }^{\circ} \mathrm{C}$ up to constant mass. Dry residue is comminuted, bolted through №250 and dried in air circulated oven at $80^{\circ} \mathrm{C}$

\section{Results and discussion}

To determine optimal parameters of montmorillonite modification processes influence of temperature and equivalence ratio on process kinetic of polyionene sedimentation on surface of crystal layers (lamenes) is studied.

Kinetic curves of polyionenes sedimentation processes at various temperatures are given on Fig. 1. According to these data all of kinetic curves are $\mathrm{S}$-shaped. Polyionenes sedimentation rate increases when temperature risen. It reach a maximum at $40^{\circ} \mathrm{C}$ (Fig. 2).

So, process of montmorillonite modification with synthesized polymeric quaternary ammonium salt is revealed to be more effective at $40^{\circ} \mathrm{C}$.

Also, influence of montmorillonite-polyionene ratio in water dispersion on polyionene content in modified montmorillonite was studied.

As it appears from represented data, modification rate and polyionene content in modified montmorillonite is strongly affected by components ratio (Fig. 3, 4).

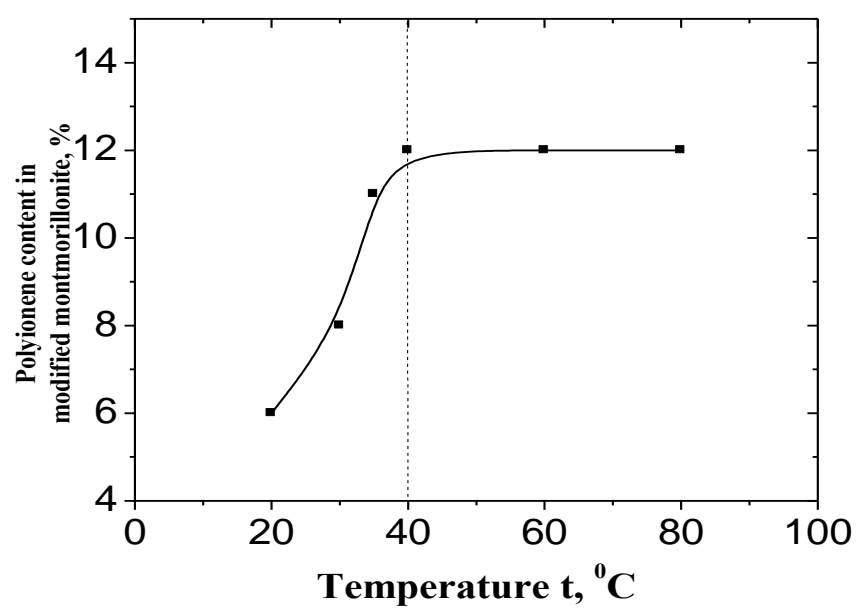

Fig. 2. Temperature dependence of polyionene content in modified montmorillonite. Montmorillonitepolyionene ratio is $3: 1$. $\tau=24$ hours 


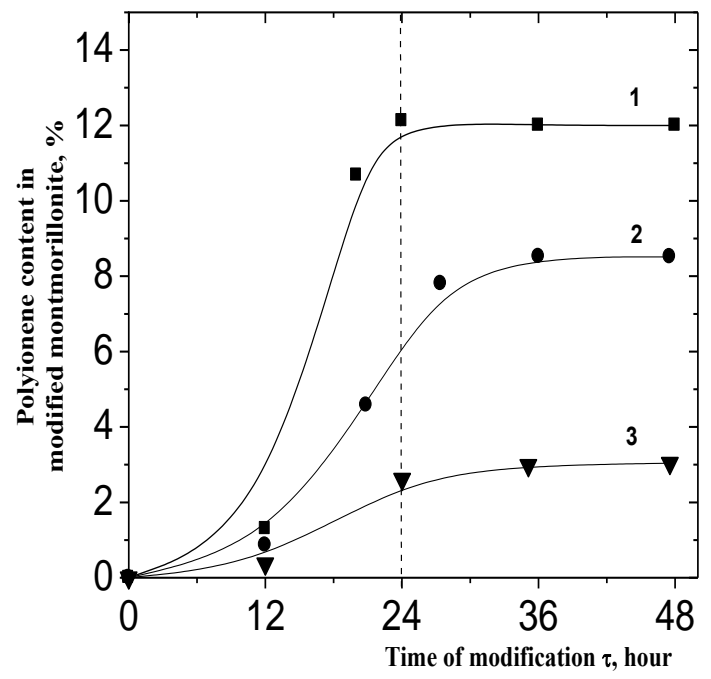

Fig. 3. Kinetic curves of montmorillonite modification process $\left(t=40^{\circ} \mathrm{C}\right)$. Montmorillonite-polyionene ratio: $1-3: 1 ; 2-5: 1 ; 3-10: 1$.

In pursuance of correlation dependence polyionene-montmorillonite ratio in water dispersion vs. polyionene-montmorillonite ratio in modified montmorillonite (Fig. 4) concentration of polyionenenes on lamenes surface is observed to abruptly increase when polyionene content achieved $20 \%$. It is supposed to be resulted from associates' formation on lamenes surface in these conditions.

Thereby, optimal regime parameters of montmorillonite polyionene modification processes are temperature of $40{ }^{\circ} \mathrm{C}$ (Fig. 1, 2) during 24 hours (Fig. 1) and montmorillonitepolyionene ration in water dispersion $3: 1$ (Fig. 3, 4).

WAXS data for montmorillonite allow to estimate a rate of cristallinity of montmorillonite and to reveal a periodicity of montmorillonite crystalline layers (lamenes) order, it being resulted in determination both of distance between montmorillonite layers and their dimension and as a consequence in identification of nanosized modified montmorillonite. WAXS profiles of studied montmorillonite are given on Fig. 5.

The unmodified montmorillonite reveal a little diffusive peak at $2 \theta=8.6^{\circ}$ corresponded technically to a distance between crystal layers $\mathrm{d}=1.03 \mathrm{~nm}$. For montmorillonite modified with polyionene peak is observed to shift into lowangles-region $2 \theta=5.8^{\circ}$. Substitution of interlayer exchange ions on polymeric cations is accompanied with increasing of distance between crystalline layers up to $1.67 \mathrm{~nm}$, both position and shape of wide angle maximum (intensivity and half-wildth) being changed because of direct

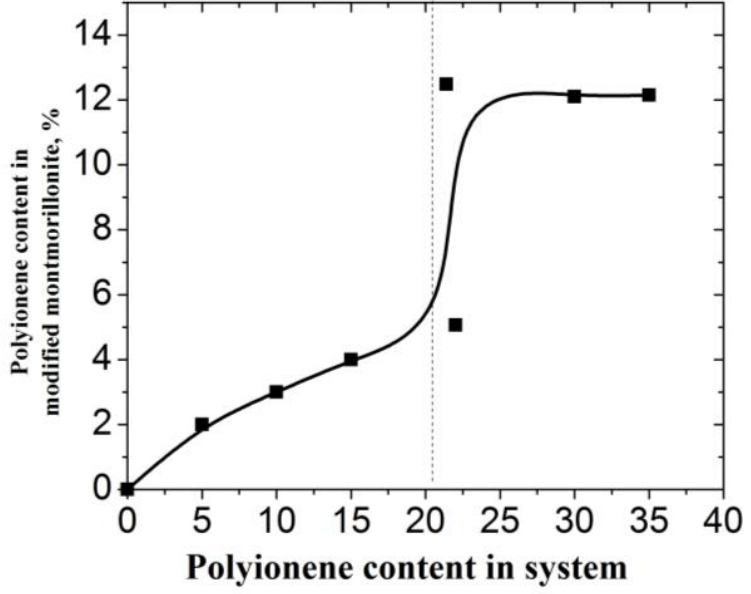

Fig. 4. Correlation dependence polyionenemontmorillonite ratio in water dispersion vs. polyionene-montmorillonite ratio in modified montmorillonite $\left(\tau=24\right.$ hours; $\left.t=40^{\circ} \mathrm{C}\right)$.

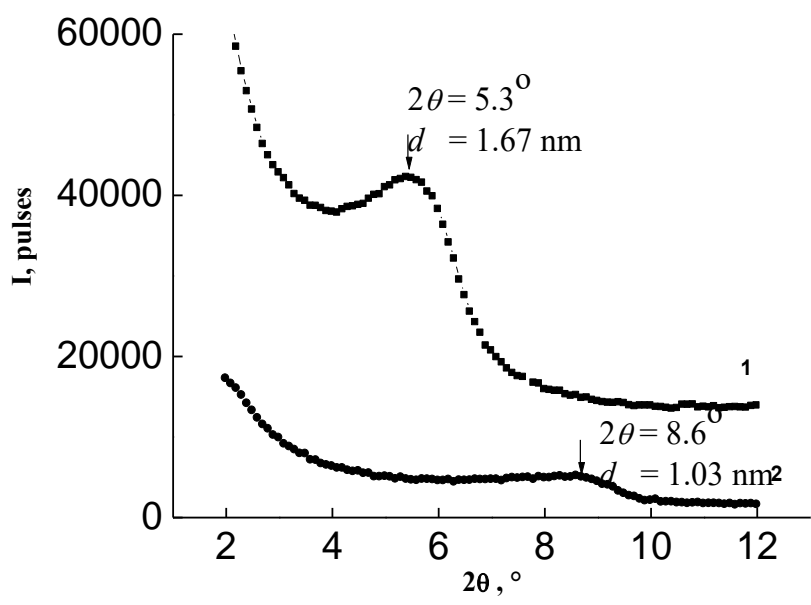

Fig. 5. WAXS profiles of montmorillonite modified with polyionene (1) and unmodified (2).

coupling with crystallinity of macrolattice, ie paracristalline order.

Increasing of interplanar spacing gives an evidence of intercalation of macromolecules fragments of modifying additive into interlayer space of montmorillonite. Accordingly, replacement of interlayer metal cations to polyionenes cations occur to resulted in decay of interlayer bonds.

Synthesized organic montmorillonites are studied by DTA method. Thermograms of initial montmorillonite, montmorillonite modified with polyionene and polyionene are given on Fig. 6.

Initial montmorillonite thermograms are characterized with double thermic endoeffect at $130{ }^{\circ} \mathrm{C}$ and $200{ }^{\circ} \mathrm{C}$ corresponded to adsorbed water loss and endoeffect at $540{ }^{\circ} \mathrm{C}$ resulted from dehydroxilation of mineral. 


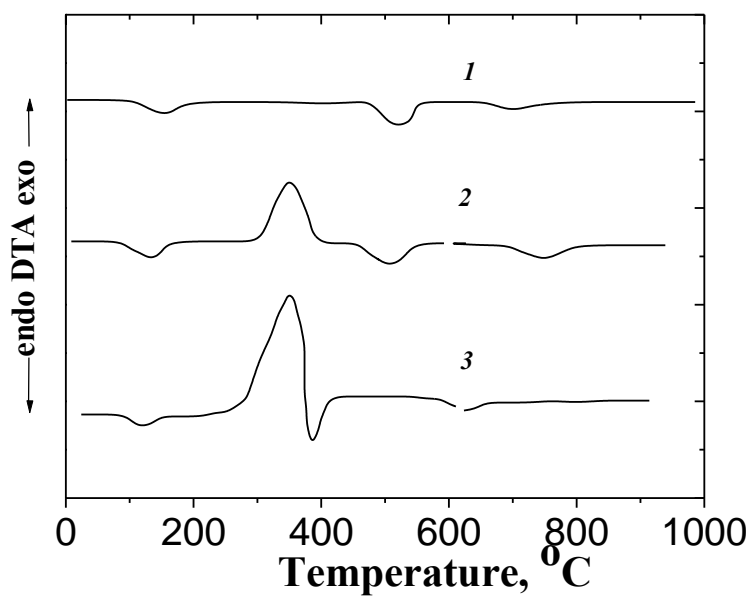

Fig. 6. Thermograms of montmorillonite (1), montmorillonite modified with polyionene (2) and polyionene (3).

On modified montmorillonite curve exothermic peak is observed at $250{ }^{\circ} \mathrm{C}$, it being accorded with polyionene decomposition. As per comparison of both corresponding exothermal and mass loss curves (Fig. 7) polyionenes content in montmorillonite is determined to be $12 \%$.

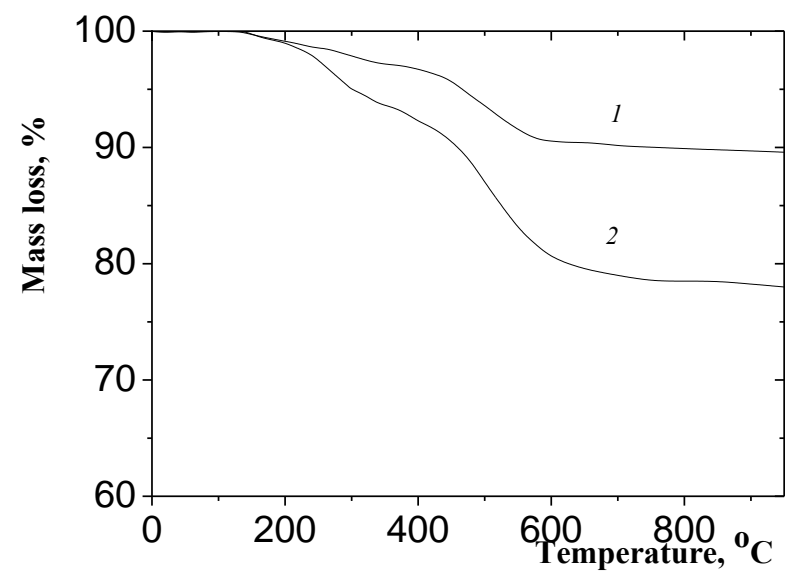

Fig. 7. Mass loss curves of montmorillonite (1) and montmorillonite modified with polyionenes (2).

IR-spectroscopy is known to reveal states of adsorbent and adsorbate and adsorption mechanism [20; 21]. With this end in view spectroscopic studies of montmorillonite modified with polyionene is carried out. When spectra initial and modified montmorillonite compared, spectra of modified montmorillonite is appeared to reveal new bands which are typical for polyionene.

So, two bands in modified montmorillonite spectra at 2930 and $2850 \mathrm{~cm}^{-1}$ correspond to valence vibrations of $\mathrm{N}-\mathrm{C}$ bond. New bands at near 1380 and $1480 \mathrm{~cm}^{-1}$ accord with vibration of $\mathrm{CH}_{2}$ - and $\mathrm{CH}_{3}$-groups connected with quaternary nitrogen atoms.
In the region of valence vibrations of structural hydroxide groups (bands at 3690, $3670,3620 \mathrm{~cm}^{-1}$ ) changes are not observed. However, interesting situation occur to be in the region of valence vibrations of $\mathrm{Si}-\mathrm{O}$. Band of $1120 \mathrm{~cm}^{-1}$ corresponded with valence vibrations of $\mathrm{Si}-\mathrm{O}$ with normal change of dipole moment against packages plane [21] reveal no distinction between initial and modified montmorillonite, but band at $970 \mathrm{~cm}^{-1}$ for initial montmorillonite is doubled into two bands at 1030 and $1010 \mathrm{~cm}^{-1}$ for modified montmorillonite, these being accorded with valence vibrations of $\mathrm{Si}-\mathrm{O}$ with parallel change of dipole moment against packages plane.

As for octahedral and tetrahedral montmorillonite layers have combine oxygen atoms lattice [22], position of valence $\mathrm{Si}-\mathrm{O}$ vibrations bands is indubitably affected by cations nature. Bands of Si-O-vibrations with dipole change in parallel to layers surface are notices to become more diffusive and shift toward low frequencies when montmorillonite structure defectiveness increased, i.e. when bonds on crystal faces torn and octahedral lattices disfigured. So, modification results in more perfect mineral structure.

Having been analyzed character of aminesclay mineral surface interaction, amines adsorption is suggested to be accompanied with bonding between surface acid OH-groups and amines nitrogen atoms [23]. Apparently, interaction of such type could be suggested. However, quaternary nitrogen atom is known to be incapable for hydrogen bond formation because of lack of undivided electron pair [23].

In that case, connection of organic cations to montmorillonite surface is assumed to be determined by attachment of organic cations to exchange position during ion-exchange adsorption and adsorption of organic cations with acid sylanol groups, i.e. torn bonds on crystal faces.

This conclusion is confirmed by comparing of the bands 770 and $730 \mathrm{~cm}^{-1}$. So, according to [24] these bands are corresponded to deformative vibrations of lattice hydroxyl groups with dipole polarization normal to layers flat surface. This conclusion is also confirmed by comparison of the bands 770 and $730 \mathrm{~cm}^{-1}$ for initial and modified montmorillonite. For example, these bands are related to deformative vibrations of lattice hydroxyl groups with dipole polarization normal to layers flat surface [22]. For modified montmorillonite these bands are observed to be 
Journal of Chemistry and Technologies, 2018, 26(1), 1-8

of more less intensity as compared with the initial montmorillonite, their absolute initensivity being almost equal.

\section{Conclusions}

Technology of obtaining of modified montmorillonite with thermostable and thermoplastic at the processing temperatures polymer quaternary ammonia salts is developed for further application when polymer nanocomposites synthesized.

Suggested mechanism of montmorillonite modification involves the next steps: connection of organic cations to montmorillonite surface determined by attachment of organic cations to exchange position during ion-exchange adsorption and adsorption of organic cations with acid sylanol groups, i.e. torn bonds on crystal faces. So, these processes result in more perfect structure by organic cations adsorption with acid sylanol groups (torn bonds on crystal faces).

Optimal conditions of polyionene molecules sorption with montmorillonite are stated to be: the concentration of aqueous dispersion of montmorillonite is $1 \%$, the temperature of the reaction medium is $40{ }^{\circ} \mathrm{C}$, the montmorillonitepolyionene ratio is $3: 1$, and the processing time is 24 hours.

\section{Acknowledgments}

This work was supported by Ministry of Education and Science of Ukraine (grant number 0116U001489).

\section{Bibliography}

[1] Wilde G. Nanostructured Materials / G. Wilde. Amsterdam: Elsevier, 2009. - 384 p.

[2] Super tough bentonite / $\mathrm{SiO}_{2}$-based dual nanocomposite hydrogels using silane as both an intercalator and a crosslinker / L. Yu, D. Wang, Yu. Tan [et al.] // Applied Clay Sci. - 2018. - Vol. 156. - P. 5360.

[3] Liborio P. New chemical treatment of bentonite for the preparation of polypropylene nanocomposites by melt intercalation/ P. Liborio, V. Oliveira, M. Marques // Applied Clay Sci. - 2015. - Vol. 111. - P. 44-49.

[4] Nicolais L. Metal-Polymer Nanocomposites / L. Nicolais, G. Carotenuto. - NY: John Wiley \& Sons, 2005. - $336 \mathrm{p}$.

[5] Koo J. Polymer Nanocomposites : Processing, Characterization, And Applications / J. Koo. - NY: McGraw Hill Professional, 2006. - 272 p.

[6] Krishnan B. Improved surface morphology of silver/copper oxide/bentonite nanocomposite using aliphatic ammoniumbased ionic liquid for enhanced biological activities / B. Krishnan, S. Mahalingam // J. Molecular Liquids. - 2017. - Vol. 241. - P. 10441058.
[7] Remediation of distilleries wastewater using chitosan immobilized bentonite and bentonite based organoclays / F. I. El-Dib, F. M. Tawfik, Gh. Eshaq [et al.] // Int. J. Biological Macromolecules. - 2016. - Vol. 86. P. 750-755.

[8] Sevim İ. Intercalation of vermiculite in presence of surfactants/ İ. Sevim // Applied Clay Sci. - 2017. Vol. 146. - P. 7-13.

[9] Malinova L. Montmorillonite modified with lactim methyl ethers having different ring sizes / L. Malinova, D. Jaksch, J. Brožek //Applied Clay Sci. - 2016. Vol. 129. - P. 20-26.

[10] Preparation and evaluation of quaternary imidazolium-modified montmorillonite for disinfection of drinking water / P. E. Kleyi, S. S. Raya, A. L. K. Abia [et al.] // Applied Clay Sci.- 2016. - Vol. 127 - 128. P. 95-104.

[11] A novel method for the preparation of inorganic and organo-modified montmorillonite essential oil hybrids / A. Giannakas, I. Tsagkalias, D. S. Achilias, A. Ladavos // Applied Clay Sci. - 2017. - 146. - P. 362-370.

[12] Characterization of montmorillonites modified with organic divalent phosphonium cations / C. S. Ezquerro, G. I. Ric, J. S. Miñana, J. S. Bermejo // Applied Clay Sci. 2015. - Vol. 111. - P. 1-9.

[13] Açışlı Ö. Investigation of the alkyl chain lengths of surfactants on their adsorption by montmorillonite (Mt) from aqueous solutions / Ö. Açışl, S. Karaca, A. Gürses // Applied Clay Sci. - 2017. - Vol. 142. P. 90-99.

[14] Bertuoli P. T. Preparation and characterization of montmorillonite modified with 3-aminopropyltriethoxysilane / P. T. Bertuoli, D. Piazza, L.S. Scienza, A. J. Zattera // Applied Clay Sci. - 2014. - Vol. 87. P. 46-51.

[15] Faghihi K. New clay-reinforced polyamide nanocomposite based on 4-phenylenediacrylic acid: Synthesis and properties / K. Faghihi, , A. S. Abootalebi, M. Shabanian, // J. Saudi Chem. Soc. - 2013. - Vol. 17. P. 191-197.

[16] Anil M. K. Polymer nanocomposites from modified clays: Recent advances and challenges / M. K. Anil, K. Bhowmick //Progress in Polymer Sci. - 2015. Vol. 51. - P. 127-187.

[17] Bee S.-L. Characterization of silylated modified clay nanoparticles and its functionality in PMMA. / S.-L. Bee, M. A. A. Abdullah, A. Mamat, // Composites Part B: Engineering. - 2017. - Vol. 110. - P. 83-95.

[18] Insight into thiabendazole interaction with montmorillonite and organically modified montmorillonites / M. Gamba, P. Kovář, M. Pospíšil, R. M. T. Sánchez // Applied Clay Sci. - 2017. - Vol. 137. - P. 59-68.

[19] Structure, thermal properties and ionic conductivity of polymeric quaternary ammonium salts (polyionenes) containing ethylene oxide and aliphatic chain fragments / M. V. Burmistr, K. M. Sukhyy, V. V. Shilov [et al] // Solid State Ionics. - 2005. - Vol. 176. P. 1787-1792.

[20] Liu L. M. Studies on nylon 6/clay nanocomposites by melt-intercalation process / L. M. Liu, Z. N. Qi, X. G. Zhu // J. Appl. Polym. Sci. - 1999. - Vol. 71. -P. 1133-1138.

[21] Ahmad Z. Dynamic-mechanical thermal analysis of aramid-silica hybrid composites prepared in a sol-gel process / Z. Ahmad, M. I. Sarwar, J. E. Mark // J. Appl. Polym. Sci. - 1997a. - Vol. 63. - P. 1345-1352.

[22] Zulfiqar S. Inclusion of aramid chains into the layered 
Journal of Chemistry and Technologies, 2018, 26(1), 1-8

silicates through solution intercalation route / S. Zulfiqar, M .I. Sarwar// J. Incl. Phenom. Macrocycl. Chem. - 2008. - Vol. 62. - P. 353-361.

[23] Mechanical and thermal properties of nano-composites of poly (vinyl chloride) and co-poly (vinyl chloridevinyl alcohol-vinyl acetate) with montmorillonite / N. Bibi, M. I. Sarwar, M. Ishaq, Z. Ahmad // Polym. Polym. Compos. - 2007. - Vol. 15. - P. 313-319.

[24] Synthesis, structure, thermal and mechanical properties of nanocomposites based on linear polymers and layered silicates modified by polymeric quaternary ammonium salts (ionenes) / M. V. Burmistr, , K. M Sukhyy, V. V. Shilov [et al.] // Polymer. - 2005. - Vol. 46. - P. 12226-12232.

\section{References}

[1] Wilde, G. (2009). Nanostructured Materials. Elsevier, Amsterdam.

[2] Yu, L., Wang, D., Tan Yu., Du, J., Huang, J. (2018). Super tough bentonite $/ \mathrm{SiO}_{2}$-based dual nanocomposite hydrogels using silane as both an intercalator and a crosslinker Applied Clay Sci. 156, 53-60. http://doi.org/10.1016/j.clay.2018.01.026

[3] Liborio, P., Oliveira, V., Marques, M. (2015). New chemical treatment of bentonite for the preparation of polypropylene nanocomposites by melt intercalation. Applied Clay Sci. 111, 44-49. http://doi.org/10.1016/j.clay.2015.04.003

[4] Nicolais, L., Carotenuto, G., 2005. Metal-Polymer Nanocomposites. John Wiley \& Sons, NY.

[5] Koo, J. 2006. Polymer Nanocomposites : Processing, Characterization And Applications: McGraw Hill Professional, NY.

[6] Krishnan, B., Mahalingam, S. (2017). Improved surface morphology of silver/copper oxide/bentonite nanocomposite using aliphatic ammoniumbased ionic liquid for enhanced biological activities. J. Molecular Liquids. 241, 1044-1058. https://doi.org/10.1016/i.molliq.2017.06.104

[7] El-Dib, F. I., Tawfik, F. M., Eshaq, Gh., Hefni, H. H. H., ElMetwally, A. E. (2016). Remediation of distilleries wastewater using chitosan immobilized Bentonite and Bentonite based organoclays. Int. J. Biological Macromolecules. 86, 750-755. https://doi.org/10.1016/j.ijbiomac.2016.01.108

[8] Sevim, İ. (2017). Intercalation of vermiculite in presence of surfactants. Applied Clay Sci. 146, 7-13. https://doi.org/10.1016/i.clay.2017.05.030

[9] Malinova, L., Jaksch, D., Brožek, J. (2016). Montmorillonite modified with lactim methyl ethers having different ring sizes. Applied Clay Sci. 129, 20-26. http://doi.org/10.1016/j.clay.2016.04.017

[10] Kleyi, P. E., Raya, S. S., Abia, A. L. K., Ubomba-Jaswa, E., Wesley-Smith, J., Maitya, A. (2016). Preparation and evaluation of quaternary imidazolium-modified montmorillonite for disinfection of drinking water. Applied Clay Sci. 127-128, 95-104. http://doi.org/10.1016/j.clay.2016.04.012

[11] Giannakas, A., Tsagkalias, I., Achilias, D. S., Ladavos, A. (2017). A novel method for the preparation of inorganic and organo-modified montmorillonite essential oil hybrids. Applied Clay Sci. 146, 362-370. http://doi.org/10.1016/j.clay.2017.06.018

[12] Ezquerro, C. S., Ric, G. I., Miñana, J. S., Bermejo, J. S. (2015). Characterization of montmorillonites modified with organic divalent phosphonium cations. Applied

Clay Sci. $111, \quad 1-9$.
http://doi.org/10.1016/i.clay.2015.03.022

[13] Açışli, Ö. Karaca, S. Gürses, A. (2017). Investigation of the alkyl chain lengths of surfactants on their adsorption by montmorillonite (Mt) from aqueous solutions. Applied Clay Sci. 142, 90-99 http://doi.org/10.1016/i.clay.2016.12.009

[14] Bertuoli, P. T., Piazza D., Scienza, L. S., Zattera, A. J. (2014). Preparation and characterization of montmorillonite modified with 3-aminopropyltriethoxysilane. Applied Clay Sci. 87, 46-51. http://doi.org/10.1016/i.clay.2013.11.020

[15] Faghihi, K., Abootalebi, A. S., Shabanian, M. (2013). New clay-reinforced polyamide nanocomposite based on 4-phenylenediacrylic acid: Synthesis and properties. J. Saudi Chem. Soc. 17, 191-197. http://doi:10.1016/i.jscs.2011.03.007

[16] Anil, M. K., Bhowmick, K. (2015). Polymer nanocomposites from modified clays: Recent advances and challenges. Progress in Polymer Sci., 51, 127-187.

[17] Bee, S.-L., Abdullah, M. A. A., Mamat, A., Bee, S.-T., Sin, L.T., Hui, D., Rahmat, A. R. (2017) Characterization of silylated modified clay nanoparticles and its functionality in PMMA. Composites Part B: Engineering. 110 83-95. http://doi.org/10.1016/i.compositesb.2016.10.084

[18] Gamba, M., Kovář, P., Pospíšil, M., Sánchez, R. M. T. (2017). Insight into thiabendazole interaction with montmorillonite and organically modified montmorillonites. Applied Clay Sci. 137, 59-68. http://doi.org/10.1016/i.clay.2016.12.001

[19] Burmistr, M. V., Sukhyy, K. M., Shilov, V. V. Pissis, P., Gomza, Yu. P. (2005). Structure, thermal properties and ionic conductivity of polymeric quaternary ammonium salts (polyionenes) containing ethylene oxide and aliphatic chain fragments. Solid State Ionics. 176, 1787-1792. http://doi.org/10.1016/j.ssi.2005.04.032

[20] Liu, L. M., Qi, Z. N., Zhu, X. G. (1999). Studies on nylon 6/clay nanocomposites by melt-intercalation process. J. Appl. Polym. Sci. 71, 1133-1138. http://doi.org/ 10.1002/(SICI)1097-4628(19990214)71:7<1133::AIDAPP11>3.0.CO;2-N

[21] Ahmad, Z., Sarwar, M. I., Mark, J. E. (1997a). Dynamicmechanical thermal analysis of aramid-silica hybrid composites prepared in a sol-gel process. J. Appl. Polym. Sci. http://doi.org/10.1002/(SICI)10974628(19970307)63:10<1345::AID-APP14>3.0.CO;2-3

[22] Zulfiqar, S., Sarwar, M. I. (2008). Inclusion of aramid chains into the layered silicates through solution intercalation route. J. Incl. Phenom. Macrocycl. Chem. 62, 353-361. http://doi.org/10.1007/s10847-008-9478-5

[23] Bibi, N., Sarwar, M. I., Ishaq, M., Ahmad, Z. (2007). Mechanical and thermal properties of nano-composites of poly (vinyl chloride) and co-poly (vinyl chloridevinyl alcohol-vinyl acetate) with montmorillonite. Polym. Polym. Compos. 15, 313-319. http://www.polymerjournals.com/pdfdownload/9953 52.pdf

[24] Burmistr, M. V., Sukhyy, K. M., Shilov, V. V., Pissis, P., Gomza, Yu. P. (2005). Synthesis, structure, thermal and mechanical properties of nanocomposites based on linear polymers and layered silicates modified by polymeric quaternary ammonium salts (ionenes). Polymer. 46, 12226-12232. http://doi.org/10.1016/i.polymer.2005.10.094 